\title{
Parties beyond national borders: exploring the activities of Israeli political parties abroad
}

\author{
Avital Friedman ${ }^{1 *}$ (D) and Ofer Kenig ${ }^{2}$
}

\author{
* Correspondence: avital. \\ friedman2@mail.huji.ac.il \\ ${ }^{1}$ The Hebrew University of \\ Jerusalem \& Israel Democracy \\ Institute, Jerusalem, Israel \\ Full list of author information is \\ available at the end of the article
}

\begin{abstract}
In recent decades it has become a common practice for political parties to have active branches operating outside of their countries. The main reason for this practice is to mobilize potential voters living abroad. Israel, however, is a country in which citizens cannot vote abroad yet some parties nevertheless invest resources for sustaining their activities and branches outside of the country. Using the Israeli case, we aim to uncover additional incentives for parties to be present and active abroad. To do so, we map the activities of Israeli parties abroad and analyse their incentives, relying on documents and in-depth interviews with the parties' directors of external relations. We find that parties' activities can be divided into two basic groups. The first one includes diaspora-oriented activities, focusing mainly on maintaining ties with the Jewish communities abroad and gaining control over the institutions of the Zionist organizations. The second is focused on the Israeli state, by both improving the position of the party domestically and promoting Israel internationally according to the party's ideology.
\end{abstract}

Keywords: Party politics, Parties abroad, Israeli politics, Diasporas, Lobbying

Heading towards the third decade of the twenty-first century, despite ongoing changes in their functioning, roles and structure, political parties remain the main actors in modern representative democracies. Parties serve as a link between the society and the state in different levels: local, regional and national. However, in recent years, there is growing evidence that parties have expanded their activity beyond the borders of their nation-state. These activities include interactions with the diaspora or with political entities outside of their national territory. The globalized economy has led to an increase in the mobility of citizens outside of their home country, creating communities of migrants in host countries. As a result, many countries extended the right to vote to their citizens living abroad. This new competitive arena motivates political parties to find new ways to mobilize potential voters abroad (Ellis 2007).

As long as the benefits of mobilizing potential voters outweigh the costs of working abroad, it makes perfectly sense for parties to do so. However, mobilizing potential voters might not be the only reason for parties to extend their activities beyond their

(c) The Author(s). 2021 Open Access This article is licensed under a Creative Commons Attribution 4.0 International License, which permits use, sharing, adaptation, distribution and reproduction in any medium or format, as long as you give appropriate credit to the original author(s) and the source, provide a link to the Creative Commons licence, and indicate if changes were made. The images or other third party material in this article are included in the article's Creative Commons licence, unless indicated otherwise in a credit line to the material. If material is not included in the article's Creative Commons licence and your intended use is not permitted by statutory regulation or exceeds the permitted use, you will need to obtain permission directly from the copyright holder. To view a copy of this licence, visit http://creativecommons.org/licenses/by/4.0/. 
country's borders. Israel serves as an interesting case study in this respect: although it does not allow overseas voting, some of the parties are nevertheless active abroad. When the usual incentive is absent and parties' activities abroad can yet be traced, there is probably an alternative explanation. Capitalizing on the unique characteristics of the Israeli case, we seek to unravel such explanation. An additional interesting aspect of the Israeli case concerns its strong ties with the large non-Israeli Jewish diaspora. Jews abroad are involved in several ways in Israeli politics and therefore parties have interest in establishing and maintaining connections with these populations.

This paper seeks to answer three main questions: Do Israeli parties operate abroad? If so, what are their areas of activities? And what are their incentives? Since information on the issue of Israeli parties abroad is scarce, this research was formalized in an exploratory manner. Following a brief review of the literature on political parties abroad, we turn to the Israeli case and delineate some of its interesting features, mainly the absence of overseas voting and the special relations Israel holds with the large noncitizen Jewish diaspora. This is followed by an effort of exploring the ways in which the Israeli parties are active outside of Israel. Information was obtained from parties' resources, from reports in the media, as well as from in-depth interviews conducted with relevant party officials, mainly directors of external relations and members of Knesset (MKs). (see Table 1 in Appendix). This exploration uncovers the motivations of Israeli parties to be active abroad.

\section{The activities of political parties abroad}

The concept of parties abroad and the activities that fall under this umbrella has just started to be conceptualized. For instance, political parties play an obvious role in the international arena, as the governing representatives of their home states. When parties win national elections, they not only gain control of appointments to international bodies but also promote policies that fall in line with their ideological view (Lawson 2006). To illustrate, the change of government in the United States following the 2016 elections was accompanied by new policies President Trump promoted in the international arena, such as pulling the US from the Iran nuclear deal or engaging in a 'trade war' vis-à-vis several nations by imposing tariffs. The populist government that took office in Italy following the 2018 elections altered its immigration and refugee policy, a move affecting the international arena as well. However, these activities are considered to be the activities of the parties' representatives while in office and therefore should probably not fall under parties abroad category.

Probably the most recognizable and studied subfield that may be categorized under the parties abroad label is the growing engagement of parties with immigrant or expatriate communities that reside outside of the country (in the 'host country'). This can also be seen as activities related to the rules of 'parties on the ground' as classified by Katz and Mair (1993). This is the result of a globalizing world that produced mobile citizens, which in turn, persuaded increasing number of countries to allow at least some of their emigrants to vote from abroad in the 'home country' elections and sometimes even allocate specific constituencies for citizens living abroad (Ellis 2007; Lafleur 2013, 2015; Collyer 2014). This development has created a new arena for political parties and has incentivized them to establish organizational branches in foreign countries, in order to campaign and mobilize potential voters. The American case offers an illustration of 
the scope of parties' involvement abroad (Dark III 2003). The Republican Party in the United States operates 'chapters' in more than 50 countries through Republicans Overseas, an affiliated organization. The goal of the organization and its branches abroad is to inspire and facilitate the millions of Americans living abroad to engage in the political process through elections and to advocate policy. Democrats Abroad are the parallel organization, with 'committees' in 42 countries worldwide.

Thus, many established democracies are increasingly involved in the process of opening up 'transnational' electoral arenas, granting voting rights to non-resident citizens and opportunities for political parties to compete for their votes abroad. As a result, the issue is increasingly receiving the attention of scholars, focussing on electoral behaviour (Collard 2013), mobilization, and forms of representation (Lisi et al. 2015; Østergaard-Nielsen and Ciornei 2017; Sampugnaro 2017).

Another activity for parties abroad concerns the issue of fundraising. Economic resources are central to all types of political organizations, including political parties. Although direct public finance has become the main economic resource for political parties, allowing the state to step in and regulate the financial aspects of the parties (Van Biezen and Kopecky 2007; Nassmacher 2009; Koß 2010), parties still engage in raising money. This is understandably done mainly vis-à-vis donors who are residents of the 'home nation' but can also be conducted vis-à-vis donors abroad. Overseas donations for parties may, in turn, raise concerns about undesirable influence and foreign intervention in national politics, leading many countries to restrict or prohibit donations from abroad. Yet such restrictions do not always apply to individual politicians or to internal selection processes within the parties, who may engage in raising money abroad.

There are several other fields that fall under the category of parties' activities abroad. First, parties are also active vis-à-vis other parties that share a similar ideology, through international bodies of parties' alliances, often referred to as Political International. There are several transnational party networks, such as the Socialist International, Liberal International, and International Democrat Union. These organizations incorporate parties from various countries which share a similar ideology and work to spread their political views by holding meetings, publishing books, operating websites and so forth. Within the framework of the European Union, some of these transnational networks evolved and were institutionalized even further to form parliamentary groups within the European Parliament and federations of parties such as Europarties (Hix and Lord 1997; Bardi 2002; Day and Shaw 2006). Current examples of Europarties include the Party of European Socialists (PES) and the Alliance of Conservatives and Reformists in Europe (ACRE).

Thus, the democratic representation of European citizens is done not just through their national or subnational parliaments and parties but also directly through the European Parliament and via Europarties. This two-channel structure of representation is well entrenched in the EU's multi-level politics, expanding the role of political parties into the supranational arena (Deschouwer 2006; Crum and Fossum 2009).

The relationship between home and their diasporas, established by creating institutions, policies and programs for the communities abroad, often lays down the infrastructure for parties to operate. There are three common explanations for the emergence of such institutions. First, from a utilitarian perspective, by engaging with its 
diaspora community the home country can gain access to resources, such as money, new technologies and diplomatic relations with the host states. (Ketkar and Ratha 2010; Gamlen 2014; Gamlen et al. 2019). Second, maintaining institutional ties with the home states helps foster emigrants' identity and ideology of the home state (Bauböck 2009). Lastly, establishing diaspora institutions helps the home states shaping a form of governance over their citizens overseas (Gamlen 2014). While these explanations relate to the establishment of institutional ties between the home country and its diaspora, it is not inconceivable that these explanations may also be relevant at the party level.

\section{The uniqueness of the Israeli case}

Most studies on parties abroad focus on the activities of home-country parties' vis-à-vis eligible voters of emigrant communities residing in host countries. In this respect, Israel offers an interesting and unique case as it does not follow suit with such activities. First, Israeli citizens cannot vote abroad, and second, most of the activities of Israeli parties abroad are not focussed on its expatriate citizens but rather on the Jewish communities, of which very few hold Israeli citizenship.

The Israeli Election Law does not allow its emigrant citizens overseas to vote from their place of residence. The same applies to Israeli citizens that live abroad for a limited term, such as students or employees of international corporations. The only exceptions are the official state representatives stationed abroad, mainly staff of the Foreign Service, who may vote in advance in one of the embassies or consulates in the state they are stationed in. The magnitude of such officials constitutes only a fraction of the Israeli citizens residing abroad. In the 2015 elections, for example, there were about 6000 such eligible voters out of an estimated half a million Israeli citizens living abroad (Kenig and Plesner 2016). Although a commitment for the adoption of voting rights for citizens who live abroad was included in the coalition agreements of the last three governments, they were not promoted, and the issue is not on the public agenda. Thus, Israeli parties do not have a straightforward interest in maintaining relations with emigrant communities. Mobilization, campaigning and vote-seeking motivations are not relevant in this case.

Despite the lack of these motivations for parties to be active abroad Israeli parties are nevertheless present outside of Israel's national borders. The main reason for this lies in the special relations Israel maintains with the large Jewish diaspora. In this respect, it should be noted that the leadership of the Jewish diaspora played an important and active part in the struggle for independence, providing vital political and financial support. Indeed, the political institutions in the pre-state era represented not only the small Jewish population living in then Palestine but also the Jewish communities all over the world. The World Zionist Organization and its affiliated institutions, especially the Jewish Agency (which was perceived by many as a government-in-waiting) took part in many aspects in the life of the Jewish population. Interestingly, while in most cases diaspora institutions are established for emigrants leaving their home state (Gamlen 2014), this main diaspora institution, in the Jewish/Israeli case, was established well before the foundation of the state of Israel.

The independence of the Israeli state declared in 1948 raised several dilemmas concerning the role of the diaspora Jews in influencing the state of Israel. The new sovereign country included now a large non-Jewish minority that shared citizenship with the 
Jewish majority. Understandably, this minority did not see the involvement of noncitizen Jews in state affairs as legitimate. Within the Jewish majority, the relations with the diaspora also raised some serious questions. Beyond the consensus regarding the Law of Return, ${ }^{1}$ debates revolved around the level of involvement diaspora Jews should or should not have in Israel. Some offered to involve (noncitizens) Jews abroad directly in the state affairs by reserving for them special Knesset seats (Dowty 1995). This idea was rejected, but other question remained: what will be the fate of the Jewish institutions, now that they finished their historical task and an independent Jewish state was established? In the early 1950s, an ambiguous arrangement was reached between the sovereign government of Israel and the Jewish institutions, recognizing the latter continued activity in the fields of settlement, immigration and education (Arian 2005, p. 51). The ambiguity allowed Israel to maintain a close institutional relationship with the Jewish diaspora through a non-state organ and allowed the noncitizen Jews to be involved in Israeli affairs (Galnoor 1985, p. 258).

Some critical scholars regard this arrangement as a testimony to the fact that in the Israeli polity, ethnos rather than demos is the main organizing political principle. In this respect, it is claimed, the political boundaries are fuzzy due to the role of the Jewish diaspora on state affairs. For instance, organizations based on the Jewish diaspora hold statutory powers within Israel to purchase and develop the land. According to Yiftachel (1999), these extraterritorial noncitizen Jewish groups have amassed political power in Israel to an extent unmatched by any democratic state, a feature that leads him to classify Israel as an ethnocracy. Regardless of this critique, some of the Israeli parties seek to gain power in these extraterritorial Jewish organizations since they impact policies and control considerable budgets within Israel.

The Israeli case study offers several interesting insights to the study of political parties' activity abroad. First, building upon the methodology of the crucial case study, the lack of a vote-seeking incentive, makes Israel a crucial least likely case to detect parties' activities abroad (Gerring 2007). Finding such activities will suggest that there might be additional motivations for parties to operate abroad. Such motivations might be relevant to other cases as well. Secondly, the case of Israel offers an interesting differentiation between the noncitizen Jewish diaspora, and Israeli emigrants. Such a differentiation further provides for a better explanation of the parties' various motivations for acting abroad.

In order to examine the activities of Israelis parties abroad, we focus on the parties that were represented in the Knesset following the 2015 elections, excluding the Arab and the Jewish ultra-orthodox parties. This is not to say that these (excluded) parties do not conduct activities outside of Israel, only that they are not as publicized as the one conducted by the mainstream Zionist parties. We first analysed open-sourced information based on parties' resources, official documents, and media reports. Secondly, to better understand the parties' motivations we identified and approached relevant party officials, mainly directors of external relations and members of Knesset (MK). We have conducted semi-structured in-depth interviews with 6 officials from 5 different

\footnotetext{
${ }^{1}$ Enacted in 1950, the Law of Return was among the first laws legislated by the Knesset. It grants all Jews living in the diaspora the right to immigrate to Israel and gain citizenship easily, almost instantaneously. The law reflected the concept of Israel as a haven for all Jews, who as a stateless minority suffered continuous persecution.
} 
parties that were active in the 20th Knesset term (2015-2019), as well as one state official (see Table 1 in Appendix).

\section{Mapping the parties' activities abroad}

While not all parties represented in the Knesset are active abroad in the same manner, we can point upon two main areas of activity. The first type may be labelled as diaspora-oriented activities. These activities emphasize the ties with the Jewish diaspora and are mainly of institutional nature. Some of the parties have an historical obligation as well as a more direct political interest to maintain such ties. The second type is activities aimed to create and foster ties with international political and financial elites. Such activities are Israel-oriented, whether because they promote the country internationally or promote the party domestically. This type is in most cases less institutionalized. In addition, it relies mainly on the personal relations of individual politicians and party officials hence are less formal and transparent.

The distinction between the two types of activities abroad is not a clear cut, and at times may overlap when the parties create and maintain connections with influential people or groups that relate to the Jewish world. Yet, activities that are diasporaoriented usually have an institutional basis with a historical obligation and focus on the Jewish world, whereas the second type of activities have a weaker basis and focus mainly on the benefit of the party domestically.

\section{Diaspora-oriented activities}

\section{The world Zionist organization and its institutions}

The World Zionist Organization (WZO) is an international movement, established in the late nineteenth century by Theodor Herzl with the aim of promoting the establishment of a sovereign Jewish nation-state. Its supreme organ and the legislative branch is the (World) Zionist Congress. The first Congress was held in 1897 in Basel, Switzerland, attracting Jewish representatives from all over the world, and later regularly convened every one to two years in a European city. In the pre-state period, the Zionist Congress was an important organ and its decisions dictated to a large extent the path of the Zionist movement in its effort to establish the State of Israel. Following the independence of Israel in 1948, its importance has waned and today congresses convene in Jerusalem every four to five years, with the most recent one held in October 2016.

The number of congress delegates is set around 500 with the following distribution: $38 \%$ from Israel, 29\% from the United States and the rest from other countries with Jewish communities (WZO 2019). Remarkably, there is no special election to determine the distribution of Israeli delegates to the Congress. Rather, delegates are distributed to the various Israeli parties according to their strength in the last elections to the Knesset, and each party appoints its delegates. For instance, if Likud holds one-quarter of the Knesset seats, it is entitled to about $25 \%$ of the total Israeli delegates for the congress. In other countries members of the WZO elect the delegates who represent various parties and movements which may have an affiliation to Israeli parties or not.

Some Israeli parties compete in the elections to the Zionist Congress through overseas 'branches' or offices. World Likud, for instance, is a movement that acts as an 
ambassador of Likud abroad and currently has offices in 32 countries. One of its main goals is to strengthen and promote the values of Zionism in the Jewish communities and to build strong ties between its representatives abroad and the State of Israel through communication and networking including events, missions, and campaigns (World Likud, the Official Website 2018). More importantly, candidates of World Likud compete in the elections to the Zionist Congress. To illustrate, for the 36th Zionist Congress, held in 2010, 26 delegates were elected abroad as representatives of World Likud.

Similarly, the World Union of Meretz is an umbrella organization that directs the activities of different movements and organizations around the world that are connected to the political party Meretz in Israel. As such, it acts as the representative of progressive Zionism and progressive Judaism in the diaspora. Twenty-eight delegates were elected abroad for the 36th Zionist Congress as representatives (World Union of Meretz, the Official Website 2018).

The role and activities of the Zionist Congress are to a large extent obscured from the Israeli public. The media hardly pay any attention to it and the general sentiment is one of indifference. However, political parties attribute great significance to the Congress and the elections preceding it. The main incentive for them to do so lies in the fact that the Congress is the organ that selects the chairmen of several 'national institutions.' The three most resourceful institutions are the Jewish Agency, the Jewish National Fund (JNF, commonly known in its Hebrew abbreviation KKL) and United Israel Appeal (Keren Hayesod). ${ }^{2}$

Although considered relics from the pre-state period, these institutions nevertheless hold a degree of influence on policy as well as a significant amount of financial resources. For example, the Jewish National Fund organization fills $46 \%$ of seats in the Israel Land Authority board. The board is in charge of all policy decisions on the land of the state, supervises it and approves its budget. By allocating party representative to key positions such as the board of the Israel Land Authority, the parties can directly influence the policy of these institutions. Moreover, it allows for access to the financial resources these entities maintain.

As mentioned before, it is difficult to create a clear-cut distinction between the diaspora and state-oriented activities. In this case, it is evident (from the interviews) that the parties benefit from the WZO activities also domestically, by gaining access to financial resources and policy influence. Yet, such access is through the resources given to the WZO, and not to any domestic organization. The benefits of these activities, such as gaining seats in the Israel Land Authority board or the Jewish agency, were granted to the WZO, in which most representatives are from the diaspora. In order to

\footnotetext{
${ }^{2}$ The Jewish Agency mainly engaged in promoting Aliyah (immigration of Jews from the diaspora to Israel), combatting anti-Semitism, promoting Zionist and Jewish education and creating linkage between the Jewish diaspora and the state of Israel. Funded mainly by diaspora donations, it also provides alternative sources of income for social projects in Israel. The chairman of the Jewish Agency is a prestigious position. In 2018, former Labour leader Yitzchak Herzog was appointed chairman, despite the reservation of Prime Minister Netanyahu, who comes from the rival Likud party. Founded in 1901, the JNF was charged with purchasing lands intended for the settling Jewish immigrants. When the state was formed, many of its functions passed naturally to state authorities. It still owns $13 \%$ of the total land in Israel, but its main activities today involve afforestation and land development. United Israel Appeal is the fundraising arm of the Zionist movement. Founded in 1920, it operates in nearly 50 countries. Since it is often problematic for Jews worldwide to give directly to the State of Israel, this philanthropic organization serves as a solution for channeling support to Israel.
} 
gain access to such benefits, the parties need to achieve the approval of this organization and participate in that political arena.

The second incentive for Israeli parties, mainly the sectorial ones, to invest in resources in the WZO is to be able to create a link between them and the communities they relate to abroad. Israel has a multi-party system, including several sectorial parties representing specific communities. The main example for that is Yisrael Beitenu, a party that represents the former Soviet Union Jews that immigrated to Israel during the 1990s. In an interview with one of the party officials, the WZO was mentioned as a significant way to strengthen the communities' culture both in Israel and the diaspora, as well as creating ties between the individuals in it. In addition, maintaining such cultural aspects, for example, the language, can legitimize the existing of such sectorial party domestically, separating this sectorial community from the rest of the population. In this way, as mentioned in the interview with World Yisrael Beitenu CEO, the party's representatives in the Zionist Congress from all over the represented countries serve as mediators between the former Soviet Union Jews living in Israel and former Soviet Union Jews communities in the diaspora.

In addition, some of the interviews have revealed that by having a substantial effect in the WZO, parties can influence and potentially increase their domestic votes. Although the WZO is not covered by the media very often, it does affect domestic voters to some extent. This political arena, which is the source of Zionist activity and had a significant role with the establishment of Israel, is heavily linked to the Zionist ideology. By participating in it, parties are perceived by the domestic voters as Zionist, giving an incentive for also non-sectorial parties to invest resources in order to engage in this political arena.

An argument can be made that by investing in the Jewish communities abroad, Israeli parties are targeting (future) potential voters, since the Law of Return grants an almost automatic citizenship to every Jew who decides to immigrate to Israel. If vote-seeking motivation was indeed an incentive then we would have expected to see parties campaigning for the votes of the Israeli-citizen communities abroad. ${ }^{3}$ However, this is not the case.

In sum, the resources Israeli parties invest in the activities of the WZO are rather low and are mainly of organizational and operational nature. Yet such activities yield significant political benefits for the parties.

\section{Organizational links with Jewish youth movements}

Another activity some Israeli parties engage in abroad is by working with Jewish youth movements. Although there are only three parties that do so to some extent (Likud, Meretz and the Labour Party), two of them are the large mainstream parties that originated from the pre-state era. Both parties have roots dating back to the pre-state era when they established affiliated youth movements in the diaspora mainly to advocate the Zionist ideology and to encourage them to immigrate to (then) Palestine and take part in the effort for an independent Jewish state. Today, those youth organizations are not funded by the three parties and they have little to do with the organizations'

${ }^{3}$ Israel does not allow external voting, but many Israelis living abroad arrive to Israel on Election Day in order to cast their vote. 
activities. However, this historical link between the parties and the organizations still holds today, despite being looser. This link is being expressed mainly on the ideological level. Yet, according to the interviews conducted, it does contain a form of direct access to the party. This is expressed by conducting meetings and tours for the movements' members by the party officials and representatives.

\section{Israel-oriented activities}

\section{Networks with other parties}

As mentioned previously, Political Internationals are multinational alliances of political parties that share a similar ideological base. Some of the organizations are global and some are regional-based, which means - for the Israeli case - European. ${ }^{4}$ Three parties are active members of such groups. Likud is a partner of the Alliance of Conservative and Reformists in Europe (ACRE) as a regional member and has also applied for membership in the International Democratic Union (IDU). Labour Party and Meretz are members of the Progressive Alliance (PA) and the Socialist International (SI) as well as in the Party of European Socialists (PES) as observers.

Participation in such organizations requires more often than not resources from the parties to cultivate and maintain such activities. These resources include applying for such alliances, paying a yearly fee and actively participating in their conferences. Yet, these are relatively low investments.

Affiliation with these alliances may be beneficial for the parties in many ways. When parties are members (either as full members or as lower affiliation) in international organizations they create an important ability to network with similar parties from other countries and gain access to information and ideas with regards to promoting their ideology. Both interviews with Likud and Labour officials have indicated that such activities allow for a more complex deliberation between the different representatives of similar ideologies and how it is being expressed in each country. They claimed that the conferences held by the Political International are helping to open their mind to new ideas with regard to promoting policies and campaigns through lectures, discussions and learning from the experience of their peers.

Parties also have a practical incentive for such affiliation. By participating in such organizations, parties can create networks with other similar transnational parties. These sort of 'sister parties' are also political players in their respective countries affecting policies both domestically and globally. Those ties can benefit the party as a way to share ideas as well as create personal ties with the politicians and party officials of likeminded parties acting in other countries.

\section{Lobbying}

Several Israeli parties also invest resources in networking with lobby groups, mainly those who deal with Israel, as was unrevealed during the interviews conducted. The American Israel Public Affairs Committee (AIPAC) and J Street are the two main lobby groups promoting Israel affairs in the United States, in which we found participation by

${ }^{4}$ Although Israel is not a European country, it does participate in several European organizations as an observant or as a full member. 
Israeli parties. The former is associated, if not formally, with the right-wing parties (Likud, Yisrael Beitenu), while the latter with the left-wing ones (Labour Party, Meretz). Both organizations are maintaining close ties with these parties, while parties, on their part, send representatives to speak in their annual conferences, mainly ministers and MKs, and work together on promoting specific issues.

These relationships have focussed on promoting the parties' ideology through the international arena, predominantly in the US. Both AIPAC and J Street have a substantial influence on the United State politics and the policies adopted with regards to the American relationship with Israel as well as the Israeli-Palestinian conflict.

We have found through the interviews we conducted, that the ties between the parties and the Israeli-related lobby groups are less formal and more personally based. Despite promoting the parties' ideology, such activities are not funded by the parties but rather by the individual funds MKs receive. These links are predominantly based on personal ties with the party leaders and other dominant politicians. As such, these activities, expressed mainly by attending conferences abroad, are funded by public funds given to each MK. Yet these politicians are representing their party and are invited in that capacity.

By influencing the lobby groups, the Israeli parties can advocate their ideological positions not only from the Israeli direction but also from the American one. This is even more important to the opposition parties since they are less likely to affect the Israeli government's policies directly on these fields. In addition, these lobby groups can affect not just the respective governments of the countries in which they act but also international public opinion. Although these lobby groups have been created and are run by Jews living in the United States, their main interest is the Israeli state and not the Jewish world.

The participation in the conferences of the two lobby groups is often covered by the Israeli media, mainly the speeches given by the Israeli MKs. AIPAC is the larger and more veteran organization, mainly associated with the Republicans, while the smaller J Street is associated with the Democrats. This creates a new angle for Israeli politicians to scrutinize the opposite side of the political map and try to delegitimize them in the Israeli media. For example, in 2013, Ayelet Shaked from the Jewish Home criticized Israeli MKs that participated in the J Street conference, arguing it is an extreme Left organization that undermines the Zionist idea (Degel 2013).

That indicates that by taking part in these lobby groups, politicians do not only seek to affect politics across the sea and international policies but also use that in order to influence domestic voters.

\section{Fundraising Vis-à-Vis individuals abroad}

In Israel, much like other countries, the financial motivation for parties to be active abroad is irrelevant. Since the introduction of the Political Parties Financing Law (1973), parties rely mainly on public funding. Donations can still be made to parties, but they are heavily restricted and regulated, allowing parties to receive donations only from Israeli citizens who are eligible to vote in the national elections while limiting them up to 2300 NIS a year per person (approximately 540 Euro). In practice, only a 
very small portion of the parties' revenues comes from donations. In the 2013 elections, for example, $98.8 \%$ of the parties' income came from public funding, while donations accounted for only 1.2\% (The State Comptroller and Ombudsman of Israel 2016).

That being said, many politicians, especially party leaders and other prominent figures, also invest resources in networking with influential individuals, specifically businessmen for financial reasons. Such connections can benefit the party during national elections campaigns or benefit individual politicians during their intra-party primary campaigns. With regards to the national elections, although foreign donations for parties are banned, nonpartisan international organizations, funded by businessmen with partisan ties were active in Israeli politics before. The first time privately funded campaigns were traced occurred in the 1996 elections. Although not officially associated with any party and therefore not obligated to the state's regulations, they nevertheless supported distinct ideological positions each identified with one of the two main parties at that time, Likud and Labour. By the next elections, the State Comptroller had directed that such campaigns conducted by a nonpartisan body supporting the line of a specific party were enough to be considered as party affiliated and therefore were strictly prohibited. ${ }^{5}$ Yet, spending private money to support a platform is not always proven to be linked to a specific party and still occurs today. For example, in the 2015 national elections, a politically nonpartisan organization called Victory 15 (V15) worked for a change of government. Although this was an Israeli-based organization, it was funded by donations, some of them from foreign individuals and organizations (Shapira et al. 2017).

This type of international activity is usually based on personal relations and, unlike previous activities detailed in this paper, is not officially conducted by the parties. Yet such activities do provide an indirect support for the parties. In most cases the links between the parties and these foreign privately funded campaigns are not easily traced or transparent, making this type of activity intriguing and complex to detect. However, the impact of such campaigns cannot be under-estimated. These foreign, nonpartisan, private campaigns aim to affect political outcomes in Israel. They are not considered to be under the parties' donation restrictions as long as they are not proven to have ties with a specific party by promoting it.

Furthermore, the heavy restrictions on foreign donations do not apply for intra-party elections, mainly candidate selection and leadership selection ('primaries'). Candidates competing in intra-party primary contests may raise money abroad, although they are still limited by a 10,000 NIS cap for legislative primaries and 11,000 NIS for the leadership primaries election (about US $\$ 2700$ and US\$3000 respectively).

\section{Discussion}

The activities of parties abroad have recently begun to attract the attention of scholars (Van Haute and Kernalegenn 2020). This is mainly due to the fact that many parties compete over the votes of citizens living beyond the country's borders. In this study, we used the Israeli case to explore the parties' activities abroad in a setting in which the vote-seeking motivation is absent. We started by exploring whether Israeli parties

\footnotetext{
${ }^{5}$ The Israeli State Comptroller is an established institution with constitutional status, resources and expertise. It regularly inspects the activities of public authorities, and one of its main functions is monitoring issues concerning party finance.
} 
operate abroad and emphasized that despite the lack of external voting, parties are still quite involved in various activities. After mapping these activities, we then offered an explanation for the motivation of the parties to invest abroad. Due to limited information on this topic, our research was conducted in an exploratory form. We have gathered information using parties' websites and media coverage. This was complemented with a series of interviews conducted with relevant party officials, mainly directors of external relations and members of Knesset (MKs). These interviews helped to shed some light over the less formal activities of the parties as well as the motivations behind investing in activities abroad.

The historically unique relationship between the State of Israel and the Jewish diaspora adds another interesting layer to our study. That has allowed us to divide parties' activities into two types. The first one includes diaspora-focussed activities, such as the involvement of parties in the WZO activities and the connections to youth movements abroad. These activities are more dominant among the veteran parties, which have roots in the pre-state era, mainly the Likud and Labour parties. We found that on top of having a sort of historical commitment to maintaining such activities, parties have a strong incentive to continue the investments in the WZO. Such incentives include spreading the party's ideology, appointing party representatives in influential positions, expanding the party's legitimacy hence affecting domestic voters, gaining access to financial resources and maintaining relationships with the relevant communities abroad, mainly for the sectorial parties.

The second type of activities the Israeli Zionist parties are involved in is Israeli focussed. These types of activities are conducted mainly in relations to the Israeli state, whether by improving the position of the party domestically or promoting Israel on the international field according to the party's ideology. While the diaspora-oriented activities have created a new political arena in which the parties compete over power, Israeli-oriented activities are conducted more independently by each party, and they are rarely engaged with one another. Moreover, they are not as formal and often rely on personal ties of the party's officials and representatives, which lead to the fact that they are not always transparent. Such activities include creating and maintaining connections with lobby groups (mainly in the United States) and indirect fundraising through individuals abroad. The motivation of the parties to invest in such activities is mainly promoting their policies, improve the international perception of Israel around the world, influencing domestic voters and improving their position when competing over the public opinion domestically.

Building on the literature on the emergence of diaspora institutions at the state level (Gamlen 2014), these two types of activities can also be distinguished by the main motivation behind them. The main motivation for parties to participate in diasporaoriented activities are historical obligations and the motivation to foster the Jewish and partisan identity. On the other hand, Israeli-oriented activities are perceived more as having utilitarian incentives for the parties such as gaining access to ideas and finance, well as gaining internal support from potential voters.

In this study we applied the least-likely case approach to find evidence for parties operating abroad despite lacking straightforward incentives. Our findings suggest that additional incentives, other than vote-seeking, play an important part in political parties' decision to be active abroad. These incentives include spreading the party's policies 
internationally, gaining access to resources and key positions, expanding the party's legitimacy and affecting domestic voters. While these incentives are probably less dominant in countries that allow for overseas voting, they can nevertheless be relevant in them as well, and should not be overlooked.

One of the most interesting findings in this research is the unique indirect vote-seeking motivation that was identified. In many countries with voting rights for citizens abroad, the reason behind parties' investment abroad is clear - winning the support of these citizens. Yet in the Israeli case, the mechanism of vote-seeking incentive works differently. By maintaining relationships with the Jewish diaspora, the parties are perceived as Zionists in the eyes of the domestic voters. By attending conferences of lobby groups and promoting Israeli interests in the global arena, the parties not only promote their ideology externally but also signal them to the domestic voters as well as receiving a pro-Israel stamp of approval. This is even clearer when parties are using the help of campaigns funded abroad to delegitimize the opposition domestically, as it occurred during the 1996 and 2015 elections. The influence on the domestic voters has repeated in all of the interviews we have conducted, showing the significance of such an incentive.

\section{Appendix}

Table 1 Details of the interviews conducted

\begin{tabular}{llll}
\hline Party/organization & Role & Date of interview & Type of interview \\
\hline Kadima & Party representative & August 2018 & Face-to-face \\
Labour Party & Party official & June 2018 & Face-to-face \\
Likud & Party official & June 2018 & Phone \\
Meretz & Party representative & December 2018 & Face-to-face \\
Yisrael Beitenu & Party official & May 2018 & Face-to-face \\
Yisrael Beitenu & Party official & June 2018 & Phone \\
WZO & Secretary of WZO & May 2019 & Secretary of WZO \\
\hline
\end{tabular}

All of the interviews were held in Hebrew and lasted between 30 min and 1 hour

Acknowledgements

This paper was originally published as book chapter in: Friedman, A., Kenig, O. (2020). The activities of Israeli political parties abroad. More than just a voters' game. In T. Kernalegenn, E. van Haute (Eds.), Political Parties Abroad. A New Arena for Party Politics (pp. 154-167). London: Routledge.

\section{Authors' contributions}

A.F conducted the interviews, analysed the data and created the initial mapping of the activities of Israeli parties abroad. O. K analysed the historical connection of Israeli parties to the diaspora and to the broader field of parties abroad. Both authors created the final typology presented in the manuscript, as well as wrote and approved the manuscript's final version.

\section{Authors' information}

Avital Friedman is a PhD student in the Department of Political Science at the Hebrew University of Jerusalem. She is also a researcher at the Israel Democracy Institute. Her fields of research include comparative politics, party politics, and Israeli politics.

Ofer Kenig is Senior Lecturer in Ashkelon Academic College and Research Fellow in the Israel Democracy Institute. His areas of research include comparative politics, political parties, leadership and candidate selection and Israeli politics. He co-authored the books From Party Politics to Personalized Politics (OUP, 2018) and The Promise and Challenge of Party Primary Elections (McGill-Queen's University Press, 2016). 


\section{Availability of data and materials}

The data generated during the current study are not publicly available since it mainly relays on interviews that were conducted specifically for this study but are available from the corresponding author on reasonable request.

\section{Competing interests}

The authors declare that they have no competing interests.

\section{Author details}

${ }^{1}$ The Hebrew University of Jerusalem \& Israel Democracy Institute, Jerusalem, Israel. ${ }^{2}$ Ashkelon Academic College, Ashkelon, Israel.

Received: 1 June 2020 Accepted: 10 February 2021

Published online: 31 May 2021

\section{References}

Arian, A. (2005). Politics in Israel: The Second Republic. Washington, DC: CQ Press.

Bardi, L. (2002). Parties and party system in the European Union: National and supranational diminutions. In K. R. Luther, \& F. Muller-Rommel (Eds.), Political parties in the new Europe (pp. 293-322). New York: Oxford University Press.

Bauböck, R. (2009). The rights and duties of external citizenship. Citizenship Studies, 13(5), 475-499.

Collard, S. (2013). The expatriate vote in the French presidential and legislative elections of 2012: A case of unintended consequences. Parliamentary Affairs, 66(1), 213-233.

Collyer, M. (2014). A geography of extra-territorial citizenship: Explanations of external voting. Migration Studies, $2(1), 55-72$.

Crum, B., \& Fossum, J. E. (2009). The multilevel parliamentary field: A framework for theorizing representative democracy in the EU. European Political Science Review, 1(2), 249-271.

Dark III, T. (2003). The rise of a global party? American party organization abroad. Party Politics, 9(2), 241-255.

Day, S., \& Shaw, J. (2006). Transnational political parties. In R. Bellamy, D. Castiglione, \& J. Shaw (Eds.), Making European citizens (pp. 99-117). London: Palgrave Macmillan.

Degel, A. (2013). Supporting J street - Are you mad? [in Hebrew]. Retrieved from www.inn.co.il/news/news.Aspx/263009. Accessed 12 Feb 2019.

Deschouwer, K. (2006). Political parties as multi-level organizations. In R. S. Katz, \& W. Crotty (Eds.), Handbook of party politics (pp. 291-300). London: Sage.

Dowty, A. (1995). Israel's first decade: Building a civic state. In A. Ilan Troen, \& N. Lucas (Eds.), Israel - The first decade of Independence (pp. 31-50). Albany: State University of New York Press.

Ellis, A. (2007). The history and politics of external voting. In IDEA and IFE (Ed.), Voting from abroad: The international IDEA handbook on external voting (pp. 41-49). Stockholm; Mexico City: IDEA and IFE.

Galnoor, I. (1985). Steering the polity: Communication and politics in Israel. Tel Aviv: Am Oved [in Hebrew].

Gamlen, A. (2014). Diaspora institutions and diaspora governance. International Migration Review, 48(1), S180$S 217$.

Gamlen, A., Cummings, M. E., \& Vaaler, P. M. (2019). Explaining the rise of diaspora institutions. Journal of Ethnic and Migration Studies, 45(4), 492-516.

Gerring, J. (2007). Is there a (viable) crucial-case Nethod? Comparative Political Studies, 40(3), 231-253.

Hix, S., \& Lord, C. (1997). Political parties in the Europe union. London: Macmillan.

Katz, R. S., \& Mair, P. (1993). The evolution of party organizations in Europe: The three faces of party organization. American Review of Politics, 14(4), 593-617.

Kenig, O., \& Plesner, Y. (2016). Reconsidering Israel's overseas absentee voting policy. Jerusalem: The Israel Democracy Institute [in Hebrew].

Ketkar, S. L., \& Ratha, D. (2010). Diaspora bonds: Tapping the diaspora during difficult times. Journal of International Commerce, Economics and Policy, 1(2), 251-263.

Koß, M. (2010). The politics of party funding: State funding to political parties and party competition in Western Europe. Oxford: Oxford University Press.

Lafleur, J.-M. (2013). Transnational politics and the state. New York: Routledge.

Lafleur, J.-M. (2015). The enfranchisement of citizens abroad: Variations and explanations. Democratization, 22(5), $840-850$.

Lawson, K. (2006). The international law of political parties. In R. S. Katz, \& W. Crotty (Eds.), Handbook of party politics (pp. 483491). London: Sage.

Lisi, M., Belchior, A. M., \& Azevedo, J. (2015). Out of sight, out of mind? External voting and political representation of Portuguese emigrants. South European Society and Politics, 20(2), 265-285.

Nassmacher, K. H. (2009). The funding of party competition: Political finance in 25 democracies. Baden: Nomos.

Østergaard-Nielsen, E., \& Ciornei, I. (2017). Making the absent present: Political parties and emigrant issues in country of origin parliament. Party Politics, 25(2), 153-166. https://doi.org/10.1177/1354068817697629.

Political Parties Financing Law (1973). Retrieved from https://mfa.gov.l/MFA/Aboutlsrael/State/Law/Pages/Party\%20Fina ncing\%20Law.aspx. Accessed 23 Dec 2019.

Sampugnaro, R. (2017). The Italian foreign constituency and its MPs. Comparative Italian Politics, 9(2), 162-184.

Shapira, A., Luria, G., \& Plesner, Y. (2017). Regulating non-party actors in general elections. Jerusalem: The Israel Democracy Institute [in Hebrew].

The State Comptroller and Ombudsman of Israel (2016). A report on the results of the audit of the accounts of the knesset factions during the 19th Knesset [in Hebrew]. Retrieved from https://www.mevaker.gov.il/he/Reports/Report_550/599c673 b-bc23-4981-bc42-2154adbb248c/011-chap-11.pdf. Accessed 23 Dec 2019.

Van Biezen, I., \& Kopecky, P. (2007). The state and the parties: Public funding, public regulation and rent-seeking in contemporary democracies. Party Politics, 13(2), 235-254. 
Van Haute, E., \& Kernalegenn, T. (2020). Conclusion. A framework of analysis for political parties abroad. In T. Kernalegenn, \& E. van Haute (Eds.), Political parties abroad. A new arena for party politics. London: Routledge.

World Likud, the Official Website (2018). Retrieved from www.worldlikud.org.il/en/. Accessed 12 Dec 2018.

World Union of Meretz, the Official Website (2018). Retrieved from www.wum.org.il/Page.aspx?Page=2\#.XGLusVwzblU. Accessed 12 Dec 2018.

WZO (2019). World Zionist Organization - The Composition of the Zionist Congress. Retrieved from www.wzo.org.il/ congress/. Accessed 8 April 2019

Yiftachel, O. (1999). "Ethnocracy": The politics of Judaizing Israel/Palestine. Constellations, 6(3), 364-390.

\section{Publisher's Note}

Springer Nature remains neutral with regard to jurisdictional claims in published maps and institutional affiliations.

Submit your manuscript to a SpringerOpen ${ }^{\odot}$ journal and benefit from:

- Convenient online submission

- Rigorous peer review

- Open access: articles freely available online

High visibility within the field

- Retaining the copyright to your article

Submit your next manuscript at $\boldsymbol{\nabla}$ springeropen.com 